\title{
Determination of the Optimal Technological Conditions of Processing of the Alkali Alumosilicate
}

\author{
V.N. Brichkin, A.M. Gumenyuk, A.V. Panov and A.G. Suss
}

\begin{abstract}
The future development of mineral raw material base in alumina's production is vary widely with resources development of low-grade alumina stock. It is actual for countries and regions with limit or stock out of traditional bauxite raw. Significant opportunities are presents the natural aluminosilicate as part of urtite, rischorrit, ijolite and the others alkali rocks and also the dump waste products of mine-mill consist of the alumosilicates incorporated overburden rocks and stocker's middlings. At the same time essential to the efficient use such materials is considerations of their chemical and mineral composition, mole ratio in calciferousaluminosilicate dry mix, sintering temperature and other parameters that determine the recovery of valuable raw material components. The future development of raw material base for the production of alumina in the central part of Siberia is strongly associated with the development Goryachegorsk deposits of nepheline ores. Experimental results is allow to clarify chemical and mineralogical composition of sample of nepheline concentrate' obtained by Goryachegorsk field's ore beneficiation and to determine the optimal conditions for its processing with the extraction in an alkaline aluminate solution alumina and alkaline components. The obtained results establish the possibility of achieving valuable components extraction rates of more than $90 \%$, which exceeds or matches the existing level for the same raw materials, and combined with the implementation of other resource-saving solutions can rely on high efficiency of the process.
\end{abstract}

V.N. Brichkin $(\square)$ · A.M. Gumenyuk

Saint Petersburg Mining University, Saint Petersburg, Russia

e-mail: kafmetall@mail.ru

A.M. Gumenyuk

e-mail: kafmetall@mail.ru

A.V. Panov · A.G. Suss

United Company RUSAL's Engineering and Technology Centre, Moscow, Russia

e-mail: andrey.panov@rusal.com

A.G. Suss

e-mail: aleksandr.suss@rusal.com

(C) The Author(s) 2018

K.V. Anisimov et al. (eds.), Proceedings of the Scientific-Practical Conference

"Research and Development - 2016", https://doi.org/10.1007/978-3-319-62870-7_67 
Keywords Alkali alumosilicate $\cdot$ Nepheline ores and concentrates Alumina production $\cdot$ Lime-nepheline charge $\cdot$ Sintering $\cdot$ Modes Performance · Quality • Experimental research

\section{Introduction}

Widely distributed in the earth's crust is the alkali aluminum silicates with a generalized stoichiometric formula $(\mathrm{Na}, \mathrm{K})_{2} \mathrm{O} \cdot \mathrm{Al}_{2} \mathrm{O}_{3} \cdot(2 \div 6) \cdot \mathrm{SiO}_{2}$ characterized by the complexity of the material composition and varying content of the main components - aluminum oxide, silica and alkali liquor. A significant amount of alkali aluminum silicates found in plutonic rocks, that include nepheline syenite, rischorrites, ijolites, leucite, urtites, synnyrity, bolgarity and various feldspathic rocks. These rocks can be combined for the production of alumina ore and associated products $[1$, p. $121 ; 2$, p. $95 ; 3$, p. $33 ; 10$, p. $167 ; 12$, p. 653]. Virtually all mountain groups of these rocks are peculiar to large reserves and favorable mining conditions that allow for open cut mining, which causes a significant interest in these ores in countries with low arrearage of bauxite, such as Russia, USA, Canada, Venezuela, Mexico, Iran, Spain, Bulgaria and others.

Modern metallurgical complex of Russia produces about $40 \%$ of alumina from nepheline raw materials and a significant amount of associated products, including aluminum hydroxide non-metallurgical grades, Portland cement and building materials based on it, sand-lime brick, soda and potash products, mineral fertilizers, metal gallium and other materials. Basic characteristics of this production, including specific material flows are well known, and its high technical and economic indicators are a stimulus for the design and creation of new production facilities. The solution of the challenge of the national alumina short supply for primary aluminum invariably associated with the development of production on the basis of nepheline raw materials and its close substitute $[2$, p. $95 ; 3$, p. $33 ; 10$, p. 167]. The indispensable requirements for effective implementation of such plans are to solve the problems of the sum of long-term to ensure the production of raw materials, reduce energy costs and ensure an economically reasonable ratio of main and associated products, including products with high added value, and quality.

By now the basic tendencies and aspects development of raw material base for the production of alumina from high-silicon aluminum raw materials due to the identified resource urtits and rischorrits rocks of Khibiny's massif, involvement in the turnover of old rejects of apatite output and low-quality bauxite, the use of natural resources in Central and Eastern Siberia, the Table 1 [2, p. 95; 3, p. 33; 10 , p. 167]. Major reserves in keeping the raw material base of aluminum production associated with the use of aluminum and ferroalloy dross foundry production, ashes from combined heat and power plants, waste water treatment and other raw materials of anthropogenic origin [1, p. 121].

There have been some progress in solution of the most painful for the processing technology of nepheline raw material issue associated to high consumption of fuel 


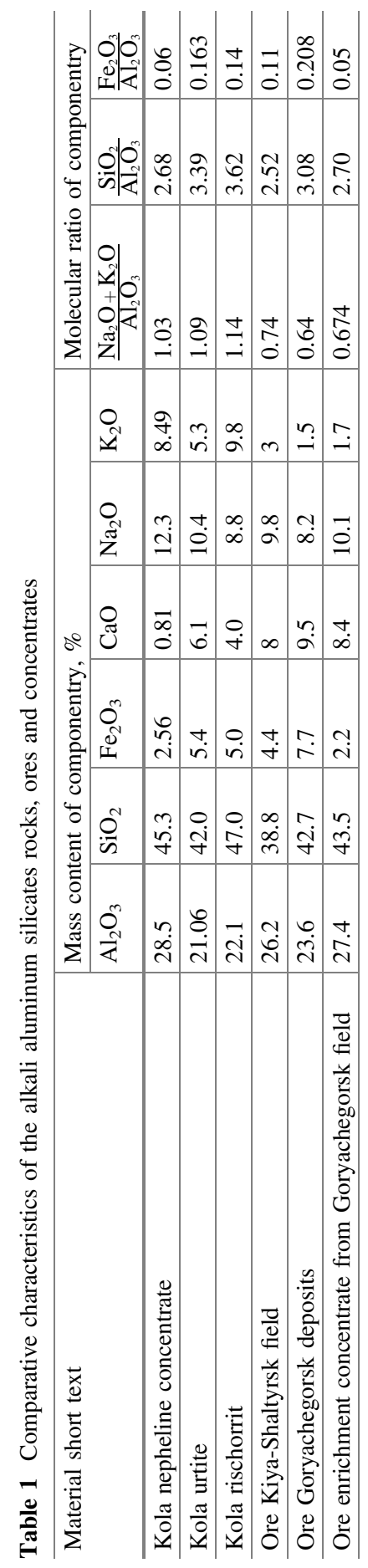


the process and, consequently, the cost of it. Upon that economically feasible approaches, including technology of dry preparation of limestone-nepheline charge and the use of low-grade fuel technology on the basis of regional deposits of lignite and coal was estimated and implemented [9, p. 420; 11, p. 11].

Securing balance the production of primary and associated products which is associated with the utilization of nepheline (belite) sludge in the production of Portland cement not a simple question. This issue theoretical elaboration, made in the 80th and 90th years of the twentieth century, in recently has become a systematic study can count on its decision [7, p. 34].

Lastly the quality of the final product invariably associated with the possibility of obtaining an aluminum hydroxide and alumina not only meets the requirements of All Union State standard, but also superior in its characteristics the existing requirements. This creates a considerable reserve for the processing of low-grade and high-silicon raw material, the production of aluminum, high-purity and innovative products in-demand in high-tech industries. The real revolution in this area is associated with the development of the theory of synthesis of metastable solid solutions in the system $\mathrm{Na}_{2} \mathrm{O}-\mathrm{Al}_{2} \mathrm{O}_{3}-\mathrm{CaO}-\mathrm{CO}_{2}-\mathrm{H}_{2} \mathrm{O}$ and Usage for extensive purification aluminate solutions from inorganic impurities and production of special binding materials $[4 ; 5 ; 6$, p. 367].

The solution of all these problems is implemented as a reference to the use of existing ore base and prospective sources of raw materials, among which the most interesting is nepheline concentrate, obtained by enrichment of ore deposits Goryachegorsk currently central. Table 1 . Represented data allow us to speak about sufficiently close chemical and modular compositions Kola nepheline concentrate and concentrate from ore beneficiation Goryachegorsk field that allows to count on obtaining satisfactory quality sintered. This is explained by arrangement of of data points sintered in the field of primary crystallization of dicalcium silicate in system $\mathrm{Na}_{2} \mathrm{O} \cdot \mathrm{Al}_{2} \mathrm{O}_{3}-\mathrm{Na}_{2} \mathrm{O} \cdot \mathrm{Fe}_{2} \mathrm{O}_{3}-2 \mathrm{CaO} \cdot \mathrm{SiO}_{2}$ far beyond the field of low-melting compounds and compositions, which creates significant opportunity for the formation of an optimal phase composition and processing properties sintered [8, p. 102].

Experimental research indicators on extraction of $\mathrm{Al}_{2} \mathrm{O}_{3}$ and sum of alkali $\left(\mathrm{Na}_{2} \mathrm{O}+\mathrm{K}_{2} \mathrm{O}\right)$ in recalculation on $\mathrm{Na}_{2} \mathrm{O}$ of flotation concentrate from Goryachegorsk deposit beneficiation of ore performed by the scheme that includes:

- fine crushing of raw materials and determining its chemical and mineralogical composition, including nepheline concentrate flotation, limestone Mozulsk mine, soda-potash mixture and circulating white slurry Achinsk alumina plant;

- calculation, preparation and chemical testing of homogeneous limestonenepheline charge with a predetermined ratio, which is determined by the stoichiometry of the main processes proceeding during sintering treatment [8, p. 102];

- briquetting of charges in compliance with the constancy of the geometrical characteristics of briquettes, compacting pressure and the mass of the crude charge; 
Table 2 Scheme of varying the chemical composition of the charge for the value of the alkaline and a limestone module

\begin{tabular}{l|l|l|l}
\hline \multirow{2}{*}{$\mathrm{M}_{\text {lime }}$} & \multicolumn{3}{|l}{$\mathrm{M}_{\text {lime }} / \mathrm{M}_{\mathrm{al}}$} \\
\cline { 2 - 4 } & $\mathrm{M}_{\mathrm{al}}=1.05$ & $\mathrm{M}_{\mathrm{al}}=1.1$ & $\mathrm{M}_{\mathrm{al}}=1.15$ \\
\hline 1.9 & $1.9 / 1.05$ & $1.9 / 1.1$ & $1.9 / 1.15$ \\
\hline 2.0 & $2.0 / 1.05$ & $2.0 / 1.1$ & $2.0 / 1.15$ \\
\hline 2.1 & $2.1 / 1.05$ & $2.1 / 1.1$ & $2.1 / 1.15$ \\
\hline
\end{tabular}

- sintering of charges in compliance with the constant duration of temperature exposure, heat treatment and cooling of the sintered;

- leaching sintered in terms of modeling the production engineering process, along terms of preparation sintered, lixiviating, filtering and washing the slurry, and conducting chemical and phase analysis of nepheline sludge and aluminate solution.

Taking into account the ultimate value for the process evolution of sintered and further extraction of valuable components of the sintering temperature and the chemical composition of the charge [8, p. 102], it defined molar ratios, varying the scheme are given in Table 2:

$$
\mathrm{M}_{\mathrm{al}}=\mathrm{Na}_{2} \mathrm{O} /\left(\mathrm{Al}_{2} \mathrm{O}_{3}+\mathrm{Fe}_{2} \mathrm{O}_{3}+\mathrm{SO}_{3}\right) \text { и } \mathrm{M}_{\text {lime }}=\mathrm{CaO} / \mathrm{SiO}_{2} \text {, }
$$

where: $\mathrm{M}_{\mathrm{al}}$ - alkaline unit charge; $\mathrm{M}_{\text {lime }}$ - limestone module; $\mathrm{R}_{\mathrm{n}} \mathrm{O}_{\mathrm{m}}$ - the amount moles of the corresponding oxide in the charge.

This allowed to prepare the charge that fairly close in chemical composition to the compositions given in Table 2, and their actual component and modular composition is given in Table 3 . The sintering batches was performed at a temperature isothermal exposure in 1260,1280 and $1300{ }^{\circ} \mathrm{C}$, the duration of which was $30 \mathrm{~min}$.

In order to determine useful components extraction from the obtained sintered its lixiviating was performed under the following conditions:

- leaching temperature $75 \pm 1{ }^{\circ} \mathrm{C}$;

- time of lixiviating leaching $30 \mathrm{~min}$;

- composition of soda-alkaline solution, $\mathrm{g} / \mathrm{dm}^{3}$ : $\mathrm{Na}_{2} \mathrm{O}_{\text {tot }}-53.4 ; \mathrm{Na}_{2} \mathrm{O}_{\mathrm{k}}-40.3$; $\mathrm{Na}_{2} \mathrm{O}_{\text {ang }}-13.1 ; \mathrm{Al}_{2} \mathrm{O}_{3}-31.1 ; \alpha_{\mathrm{K}}-2.1$;

- partition size matches of the sintered $100 \%$ mesh size less $0,25 \mathrm{~mm}$;

- correlation L: $\mathrm{S}=2.7$ or 18.5 grams of the sintered on $50 \mathrm{sm}^{3}$ solution;

- mixing was carried out with a propeller stirrer spinning speed of $230 \mathrm{rpm}$;

- after the leaching process slurry was filtered under vacuum and washed with hot water (about 12-fold amount relative to the weight of the slurry), after that samples to be taken for analysis and the remaining slurry was dried.

Sintered quantitative composition estimation demonstrates that the soluble phase as a solid solution and sodium aluminate ferrite (potassium) is contained in an 


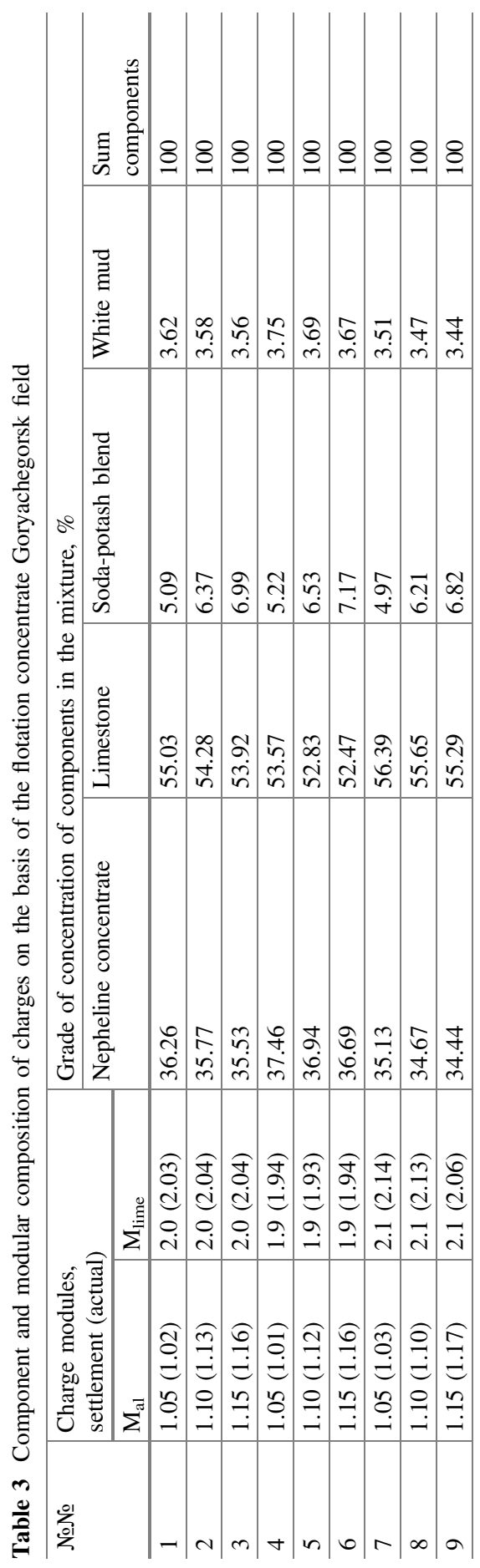


amount of $26.4 \pm 29.0 \%$ as calcium orthosilicate submitted $\beta-\mathrm{C}_{2} \mathrm{~S}$ in amount 65.0 $\pm 60.0 \%$. Contents of soda-lime silicate $\left(\mathrm{Na}_{2} \mathrm{O} \cdot \mathrm{CaO} \cdot \mathrm{SiO}_{2}\right)$ is from 1.15 to $7.0 \%$, and its presence has a negative influence on the extraction of alkali components in the solution, Fig. 1. All samples nepheline (belite) sludge was performed semi-quantitative $\mathrm{X}$-ray analysis. Based on its results we can say that the basis of all the sludge is $\beta-\mathrm{C}_{2} \mathrm{~S}$ in an amount of about $90 \%$ with a small impurity phases $\alpha \cdot-\mathrm{C}_{2} \mathrm{~S}$ in the amount of $3 \pm 5 \%$. This confirms the conclusion that loss of alkali lixiviating at a process is mainly linked to the presence of soda-lime silicate (NCS), and also partial decomposition $\alpha^{\prime}-\mathrm{C}_{2} \mathrm{~S}$ phases to form a number of $\mathrm{X}$-ray amorphous products are not subject to quantify and lead to losses valuable components $[2$, p. $95 ; 8$, p. $102 ; 10$, p. 167].z

Whereupon the most favorable conditions for extracting alumina and alkalis in processing flotation concentrate from the ore beneficiation Goryachegorsk deposits are formed using a saturated batches, corresponding to the following actual values

Fig. 1 The dependence of extraction of alkalis on the content of the soda-lime silicate (NCS) in the sinter
Fig. 2 Dependence of chemical extraction of $\mathrm{Na}_{2} \mathrm{O}$ and $\mathrm{Al}_{2} \mathrm{O}_{3}$ in the aluminate solution on the sintering temperature of the limestone-nepheline charge: $1-\mathrm{Na}_{2} \mathrm{O} ; 2-\mathrm{Al}_{2} \mathrm{O}_{3}$
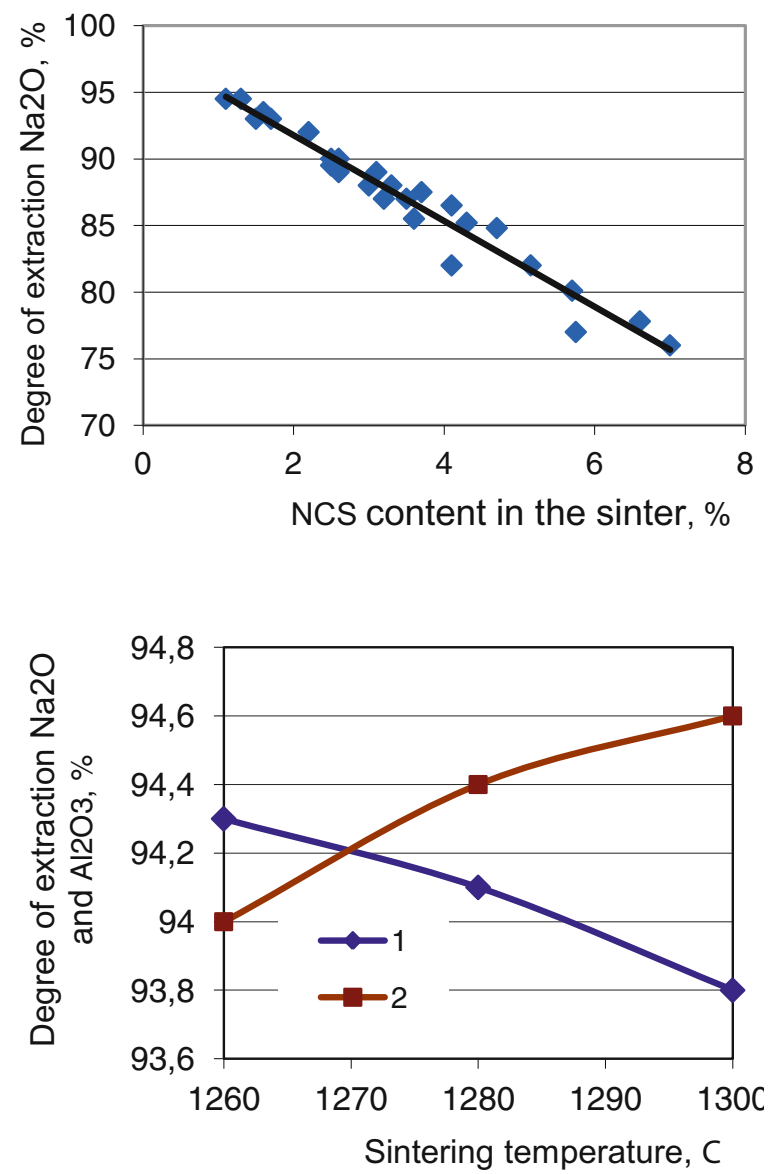
of charge units $\mathrm{M}_{\mathrm{al}}=1.01$ and $\mathrm{M}_{\text {limestone }}=2.02$, Fig. 2. Analysis of obtained results shows that for sintering concentrate of the Goryachegorsk ores most optimal are the following parameters of the process: sintering temperature- $1280 \pm 5{ }^{\circ} \mathrm{C}$; $\mathrm{M}_{\text {limestone }}-1.9 \div 2.0 ; \mathrm{M}_{\mathrm{al}}-1.0 \pm 0.05$. With these parameters, the sintering process of recovery in the aluminate liquor (determined by solid phase) for in the lixiviating of $\mathrm{Al}_{2} \mathrm{O}_{3}=94.4 \%$ and $\mathrm{Na}_{2} \mathrm{O}=94.1 \%$, that is at the level of indicators of ore processing Chia-Shaltyrsk field.

\section{Conclusions}

1. It has been shown that the modular characteristics of limestone-based charge nepheline concentrate Goryachegorsk field and its sintering temperature within accepted ranges of variation are essential extracting alumina and alkali aluminate in solution.

2. It has been established experimentally that the indicators of the extraction of valuable components of nepheline concentrate, determined by the conditions of formation of phase composition sintered and its physical characteristics. It ensures the achievement of components extraction rates at the level of processing of ore base, which allows counting on the effective involvement in the production turnover of nepheline raw Goryachegorsk field.

Acknowledgements Research are carried out (conducted) with the financially support of the state represented by the Ministry of Education and Science of Russian Federation. Agreement (contract) no. 14.577.21.0208 02 nov.2015. Unique project Identifier: RFMEFI57715X0208.

\section{References}

1. Алюминиевое сырьё/ А.В., Акимова, О.С. Березнер, Н.В. Дудкин и др. // Государственный доклад «О состоянии и использовании минерально-сырьевых ресурсов Российской Федерации в 2011 году» . Центр «Минерал» ФГУНПП «Аэрогеология» , 2012. С. 121-129

2. Бричкин В.Н. Спекание известняково-нефелиновой шихты с добавкой рисчорритовых пород Хибинского массива / В.Н. Бричкин, М.В. Черкасова, А.М. Гуменюк // Вестник Иркутского Государственного технического университета, 2016. № 2. С. 95-99

3. Обогащение лежалых хвостов флотации апатит-нефелиновых руд / В.М. Сизяков, Ю.П. Назаров, В.Н. Бричкин, Е.В. Сизякова // Обогащение руд, 2016. №2. С. 33-40

4. Патент №.2560412, РФ. Способ обескремнивания алюминатных растворов / В.М. Сизяков, В.Н. Бричкин, Е.В. Сизякова, В.В. Васильев // Опубликовано: 20.08.2015 Бюл. № 23

5. Патент №.2560413, РФ. Способ глубокого обескремнивания алюминатных растворов / В.М. Сизяков, В.Н. Бричкин, Е.В. Сизякова, В.В. Васильев // Опубликовано: 20.08.2015 Бюл. № 23 
6. Сизяков В.M. Модернизация технологии комплексной переработки Кольских нефелиновых концентратов на Пикалёвском глинозёмном комбинате // Цветные металлы-2010. Красноярск: ООО «Версо», 2010. С. 367-378

7. Сизяков В.М. Повышение комплексности переработки нефелинового сырья на основе содовой конверсии белитового шлама / В.М. Сизяков, В.Н. Бричкин, Р.В. Куртенков // Обогащение руд, 2016. №1. С. 34-39

8. Сизяков В.М. Химико-технологические закономерности процессов спекания щелочных алюмосиликатов и гидрохимической переработки спеков // Записки Горного института, 2016. Т. 217. С. $102-112$

9. Финин Д.В. Использование бурого угля на переделе спекания глиноземного комбината / Д.В. Финин, С.Н. Горбачев, М.А. Кравченя // Цветные металлы 2013. Сб. докладов $4^{\text {го }}$ международного конгресса. Красноярск: «Версо», 2013. С. 420-425

10. Черкасова М.В. Современные тенденции в переработке низкокачественного алюминиевого сырья и их влияние на развитие минерально-сырьевой базы производства глинозема / М.В. Черкасова, В.Н. Бричкин // Горный информационно-аналитический бюллетень (научно-технический журнал), 2015. №19. С. 167-172

11. Sine Bøgh Skaarup. Dry Sintering of Nepheline-A New More Energy Efficient Technology . Sine Bøgh Skaarup, Y.A. Gordeev, V.V. Volkov . Light Metals, 2014. pp. 111-116

12. Virginia T. McLemore. Nepheline Syenite. Industrial Minerals and Rocks, 2003. pp. 653-670

Open Access This chapter is licensed under the terms of the Creative Commons Attribution 4.0 International License (http://creativecommons.org/licenses/by/4.0/), which permits use, sharing, adaptation, distribution and reproduction in any medium or format, as long as you give appropriate credit to the original author(s) and the source, provide a link to the Creative Commons license and indicate if changes were made.

The images or other third party material in this chapter are included in the chapter's Creative Commons license, unless indicated otherwise in a credit line to the material. If material is not included in the chapter's Creative Commons license and your intended use is not permitted by statutory regulation or exceeds the permitted use, you will need to obtain permission directly from the copyright holder.

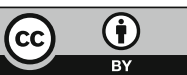

